\title{
Kidney involvement in coronavirus-associated diseases (Review)
}

\author{
ZHICAI FENG ${ }^{1}$, YUQING CHEN ${ }^{2}$, YUQIN WU ${ }^{3}$, JIANWEN WANG ${ }^{1}$, HAO ZHANG $^{1}$ and WEI ZHANG ${ }^{1}$ \\ ${ }^{1}$ Department of Nephrology, The Third Xiangya Hospital, Central South University, Changsha, Hunan 410013; \\ ${ }^{2}$ The Graduate School of Fujian Medical University, Fuzhou, Fujian 350108; ${ }^{3}$ Department of Radiology, \\ The First Hospital of Changsha, Changsha, Hunan 410011, P.R. China
}

Received June 15, 2020; Accepted January 5, 2021

DOI: $10.3892 /$ etm.2021.9792

\begin{abstract}
Since 2003, coronaviruses have caused multiple global pandemic diseases, including severe acute respiratory syndrome (SARS), Middle East respiratory syndrome (MERS) and coronavirus disease 2019 (COVID-19). Clinical and autopsy findings suggest that the occurrence of kidney injury during infection may negatively affect the clinical outcomes of infected patients. The authoritative model predicts that outbreaks of other novel coronavirus pneumonias will continue to threaten human health in the future. The aim of the present systematic review was to summarize the basic knowledge of coronavirus, coronavirus infection-associated kidney injury and the corresponding therapies, in order to provide new insights for clinicians to better understand the kidney involvement of coronavirus so that more effective therapeutic strategies can be employed against coronavirus infection in the future.
\end{abstract}

\section{Contents}

1. Introduction

2. SARS-CoV and kidney injury

3. MERS-CoV and kidney injury

4. SARS-CoV-2 and kidney injury

5. Comparison of kidney injury among SARS-CoV, MERS-CoV and SARS-CoV-2

6. Possible mechanism of coronavirus-associated kidney injury

7. Coronavirus and blood purification

8. Conclusion

Correspondence to: Dr Wei Zhang or Professor Hao Zhang, Department of Nephrology, The Third Xiangya Hospital, Central South University, 138 Tongzipo Road, Changsha, Hunan 410013, P.R. China

E-mail: weizhangxy@126.com

E-mail: zhanghaoliaoqing@163.com

Key words: coronavirus, kidney injury, severe acute respiratory syndrome, Middle East respiratory syndrome, coronavirus disease 2019

\section{Introduction}

Coronavirus pneumonia is a respiratory infectious disease caused by coronavirus infection. Since the severe acute respiratory syndrome coronavirus (SARS-CoV) spread and caused infection globally in 2003, coronaviruses have gradually attracted public attention and have caused several serious epidemics (1-3).

Coronaviruses are a group of single-stranded positive-sense RNA viruses, of which 26 species are currently known $(4,5)$. Based on their differences in antigen cross-reactivity and genetic composition, they are divided into 4 genera $(\alpha, \beta, \gamma$ and $\delta)$, of which only genera $\alpha$ and $\beta$ contain strains that are pathogenic to humans (6-8). SARS-CoV-2 (the 2019 novel coronavirus), SARS-CoV and Middle East respiratory syndrome coronavirus (MERS-CoV) belong to the $\beta$-coronavirus family $(9,10)$. There are seven known coronaviruses that may cause human diseases, including HCoV-229E, HCoV-OC43, HCoV-NL63, HCoV-HKU1, SARS-CoV and MERS-CoV $(11,12)$ and the newly discovered SARS-CoV-2 (13). These viruses may cause a variety of clinically critical conditions, including kidney injury. The aim of the present systematic review was to summarize the knowledge of coronavirus infection from the perspective of kidney injury.

\section{SARS-CoV and kidney injury}

SARS was first reported in Asia in early 2003, and similar diseases were subsequently reported in North America and Europe $(14,15)$. Of a total of 8,422 patients diagnosed with SARS, 916 succumbed to the disease, bringing the case fatality rate to $10.87 \%$ (16). SARS-CoV was found to be the main pathogen of SARS based on the findings from a macaque infection model (17). SARS-associated coronavirus was the SARS pathogen identified from the Macaca fascicularis infection experiment (18). During the SARS-CoV infection, $100 \%$ of adult and pediatric patients had fever, approximately half of all patients had cough and/or myalgia, and a small number of patients experienced upper respiratory symptoms $(19,20)$. In $10-20 \%$ of the patients, blood urea nitrogen and urine creatinine levels were increased, indicating that SARS may directly or indirectly cause kidney injury (Table I) (21-26). Chu et al (21) reported that kidney involvement in SARS was significantly correlated with the severity of the disease, and that patients with chronic diseases were more likely to suffer from kidney 
injury. Autopsy reports of some patients with SARS indicated local renal hemorrhage and varying degrees of acute tubular necrosis (27). In situ hybridization and electron microscopy indicated the presence of viral sequences and particles, respectively, in distal renal tubular epithelial cells (27-29). The presence of the virus in the distal tubules may explain the findings of viral RNA and isolation of SARS-CoV from urine samples (30-32).

\section{MERS-CoV and kidney injury}

The earliest reports of MERS can be traced back to June 2012, when MERS-CoV was isolated from a patient in Saudi Arabia who succumbed to severe respiratory disease (33). By December 2019, there were 868 reported deaths among 2,496 MERS cases worldwide, with a case fatality rate of $34.77 \%$ (16). Researchers indicated that MERS-CoV, the causative agent of the disease, may originate from bats (11), with dromedary as its intermediate host (34). The clinical manifestations in patients with MERS-CoV infection range from asymptomatic to severe infectious pneumonia, acute respiratory distress, septic shock and multiple organ failure leading to death (11). Approximately $40 \%$ of patients exhibited increased urine creatinine levels, suggesting that MERS-CoV may cause kidney injury in some patients (Table I) (35-37). In vitro infection experiments with primary human renal epithelial cells (PromoCell) revealed that MERS-CoV robustly replicated in culture and produced more infectious virions (38). Poissy et al (39) reported that the virus could be detected in the blood and the urine of their most severely ill patients with MERS-CoV infection. Patients with MERS-CoV infection usually manifested with early and rapid-onset acute renal failure, which adversely affected the disease progression (38-41). Alsaad et al (42) indicated that, in patients with MERS-CoV infection, the kidney displayed the characteristics of renal tubular epithelial cell degeneration and regeneration/acute kidney injury (AKI). Ng et al (43) found that, in patients with MERS-CoV infection, the kidney exhibited an increase in global sclerosing glomeruli, affecting $5-10 \%$ of the total glomeruli; thickening Bowman capsules; severe atherosclerosis and hyaline arteriolosclerosis; patchy interstitial inflammation; and intratubular proteinaceous and granular casts.

\section{SARS-CoV-2 and kidney injury}

Coronavirus disease 2019 (COVID-19) is an infectious disease caused by a novel coronavirus $(44,45)$. The pathogen of this disease, SARS-CoV-2, shows $75-80 \%$ similarity to the nucleotide sequence of SARS-CoV (45-47). The bat is presumed to be its animal host and an intermediate host (48-50). Although the main target organ of SARS-CoV-2 is the lung, several studies have demonstrated that SARS-CoV-2 may also induce kidney injury; $5-30 \%$ of patients exhibit increase blood urea nitrogen and urine creatinine levels and kidney injury, indicating that the kidney is also targeted by SARS-CoV-2 (Table I) (13,51-56). During the current COVID-19 pandemic, 4-7\% of patients infected with SARS-CoV-2 developed AKI, and the AKI incidence may be even higher among patients with severe symptoms admitted to the intensive care unit (ICU) (51).
Huang et al (54) analyzed 41 patients with SARS-CoV-2 infection and found that $>10 \%$ had elevated creatinine levels. Among patients treated in the ICU, 23\% had AKI. Patients with kidney injury (including increased creatinine and urea nitrogen, proteinuria, hematuria and $\mathrm{AKI}$ ) were more likely to die in the hospital in a study of 710 patients with COVID-19. Cox regression analysis confirmed that kidney injury is one of the independent risk factors for poor prognosis (57). Su et al analyzed renal pathologies in 26 autopsies of patients with COVID-19 and found prominent acute proximal tubular injury, peritubular erythrocyte aggregation and glomerular fibrin thrombi with ischemic collapse (58). In another study, 251 of 333 patients $(75.4 \%)$ presented with renal complications, including proteinuria, hematuria and AKI. Although renal complications often resolved within 3 weeks after the onset of symptoms, renal complications in COVID-19 were associated with higher mortality (59).

\section{Comparison of kidney injury among SARS-CoV, MERS-CoV and SARS-CoV-2}

Previous studies have reported that patients infected with SARS-CoV, MERS-CoV or SARS-CoV-2 may present with AKI, but the incidence across studies was not consistent. AKI was reported to develop in 5-15\% cases of SARS and MERS-CoV infections, whereas early reports suggested a lower incidence of AKI among patients with COVID-19 infection $(13,51)$. Chen et al $(60)$ found that the mortality rate of AKI was highest in SARS (86.6\%), followed by COVID-19 (76.5\%) and MERS (68.5\%). Autopsy results in patients with SARS-CoV infection revealed that the kidney exhibited local hemorrhage and different degrees of acute tubular necrosis instead of glomerular lesions $(21,27)$. Unlike SARS, a MERS autopsy report revealed that the kidney had the characteristic of epithelial cell degeneration and regeneration, but the size and shape of the glomeruli were normal, with only minor ischemic changes (42). Su et al (58) analyzed renal pathologies in 26 autopsies of patients with COVID-19 and found prominent acute proximal tubular injury, peritubular erythrocyte aggregation and glomerular fibrin thrombi with ischemic collapse. Ding et al (29) reported that SARS-CoV was detected in distal convoluted renal tubules. In situ hybridization and electron microscopy also indicated the presence of viral sequences and particles, respectively, in distal renal tubular epithelial cells (27-29). MERS-CoV particles were localized in renal proximal tubular epithelial cells (42). SARS-CoV-2 particles were identified by electron microscopy in the cytoplasm of renal proximal tubular epithelial cells and podocytes, but less so in the distal tubules (58). Interestingly, all three coronaviruses were isolated from urine samples $(30-32,61,62)$.

\section{Possible mechanism of coronavirus-associated kidney injury}

Kidney injury in coronavirus infection is mainly due to the ability of coronavirus proteins to bind to specific cell surface receptors (63-65). To date, two major functional receptors for coronavirus have been identified:

Angiotensin-converting enzyme 2 (ACE2) is mainly expressed in the lung, kidney, heart and other tissues; 
Table I. Kidney involvement in coronavirus infection.

\begin{tabular}{|c|c|c|c|c|c|}
\hline \multirow[b]{2}{*}{ Study (Refs.) } & \multicolumn{2}{|c|}{ Blood urea nitrogen ${ }^{\mathrm{a}}$} & \multicolumn{2}{|c|}{ Creatinine $^{\mathrm{b}}$} & \multirow[b]{2}{*}{$\begin{array}{l}\text { Acute kidney } \\
\text { injury }[\text { no./total }(\%)]\end{array}$} \\
\hline & $\begin{array}{c}\text { Normal } \\
(\text { value } \pm \mathrm{SD})\end{array}$ & $\begin{array}{c}\text { Increased } \\
{[\text { no./total }(\%)]}\end{array}$ & $\begin{array}{c}\text { Normal } \\
(\text { value } \pm \mathrm{SD})\end{array}$ & $\begin{array}{c}\text { Increased } \\
{[\text { no./total }(\%)]}\end{array}$ & \\
\hline \multicolumn{6}{|l|}{ SARS } \\
\hline Chu et al (21) & $4.6 \pm 4.8$ & NA & $93.5 \pm 48.7$ & NA & $36 / 536(6.7)$ \\
\hline Lu et al (22) & NA & 167/801 (20.9) & NA & 89/801 (11.2) & NA \\
\hline Lee et al (23) & $6.3 \pm 7.2$ & NA & $99.0 \pm 111.8$ & NA & NA \\
\hline Hsu et al (24) & $3.2 \pm 1.5$ & NA & $65.4 \pm 12.4$ & NA & NA \\
\hline Jang et al (25) & NA & NA & NA & $6 / 29(20.7)$ & NA \\
\hline Cheng et al (26) & $5.3 \pm 1.8$ & 24/142 (16.9) & $86.0 \pm 16.0$ & 14/142 (9.9) & NA \\
\hline \multicolumn{6}{|l|}{ MERS } \\
\hline Sun et al (35) & NA & NA & $89.9 \pm 28.3$ & NA & NA \\
\hline AlGhamdi et al (36) & NA & NA & NA & $21 / 51(41.2)$ & NA \\
\hline Sherbini et al (37) & $14.2 \pm 2.1$ & NA & $148.3 \pm 29.3$ & NA & NA \\
\hline \multicolumn{6}{|l|}{ COVID-19 } \\
\hline Chen et al (13) & $5.9 \pm 2.6$ & $6 / 99(6.1)$ & $75.6 \pm 25.0$ & 3/99 (3.0) & 3/99 (3.0) \\
\hline Wang et al (51) & $4.4 \pm 1.4$ & NA & $72.0 \pm 21.0$ & NA & $5 / 138(3.6)$ \\
\hline Guan et al (52) & NA & NA & NA & $12 / 752(1.6)$ & 6/1099 (0.5) \\
\hline Yang et al (53) & NA & NA & $76.3 \pm 27.4$ & NA & 15/52 (28.8) \\
\hline Huang et al (54) & NA & NA & $74.2 \pm 19.5$ & 4/41 (9.8) & 3/41 (7.3) \\
\hline $\mathrm{Xu}$ et al (55) & NA & NA & NA & $3 / 62(4.8)$ & NA \\
\hline Cai et al (56) & $4.0 \pm 0.9$ & NA & $63.0 \pm 13.4$ & NA & $17 / 298(5.7)$ \\
\hline Su et al (58) & $16.1 \pm 2.7$ & NA & $99.7 \pm 16.2$ & NA & NA \\
\hline Pei et al (59) & $4.3 \pm 1.2$ & NA & $70.0 \pm 13.5$ & NA & $35 / 333(10.5)$ \\
\hline
\end{tabular}

${ }^{\mathrm{a} N o r m a l ~ r a n g e, ~ 3.6-9.5 ~ m m o l / 1 . ~}{ }^{\mathrm{b}} \mathrm{Normal}$ range, 57.0-111.0 $\mu \mathrm{mol} / \mathrm{l}$. SARS, severe acute respiratory syndrome; MERS, Middle East respiratory syndrome; COVID-19, coronavirus disease 2019; NA, not available.

in the kidney, this protein is prominently expressed in the proximal tubule and at a lower level in the glomeruli $(66,67)$. Dipeptidyl peptidase 4 (DPP4; also referred to as CD26) is also highly expressed in the kidney, small intestine and lung (68-70). DPP4 is also one of the renal tubular brush border membrane proteins and is present in glomerular podocytes and capillaries (71). The expression levels of ACE2 and DPP4 in normal tissues were examined by searching two public databases, A Database of Hepatocellular Carcinoma Expression Atlas (http://lifeome. net/database/hccdb/home.html) (72) and the Human Protein Atlas (HPA; https://www.proteinatlas.org/) (73,74). At the RNA level, the expression level of ACE2 in kidney tissues was higher compared with that in lung tissues (Fig. 1A and C), which is consistent with previous reports by Xu et al (75) and Hoffmann et al (76). The DPP4 expression in the kidney was also higher compared with that in the lung (Fig. 1B and D). ACE2 was abundantly expressed in the kidney (77), mainly in the brush border of the proximal tubule $(65,78)$, which was consistent with immunohistochemistry results in the HPA (Fig. 1E). Pala et al (79) found that DPP4 was abundantly expressed in human glomerular endothelial cells, which was also consistent with the immunohistochemistry results in the HPA (Fig. 1E).
ACE2 is a functional receptor for SARS-CoV $(80,81)$. Li et al (67) isolated the ACE2 protein from African green monkey (Chlorocebus sabaeus) kidney cells (VERO E6) infected with SARS-CoV, showing that ACE2 could efficiently bind to the $\mathrm{S}$ protein for the SARS-CoV. SARS-CoV efficiently replicated in 293 T cells transfected with ACE2; however, when anti-ACE2 antibodies were added to the culture media, SARS-CoV was unable to replicate in 293 T cells transfected with ACE2 (82). Batle et al (83) found that only a few cell lines could be naturally infected by SARS-CoV, but when they were modified to express ACE2, the virus could infect and replicate in other cells. ACE2 expression is associated with virus titer. Yang et al (84) found that high ACE2 expression resulted in more serious SARS-CoV infection in mice. Analogous to other virus-receptor interactions, SARS-CoV spike protein binding to ACE2 in cell lines or SARS-CoV infections in vivo resulted in reduced ACE2 protein expression and aggravated lung injury (80). Both SARS-CoV RNA and viral particles were observed in kidney tubules in SARS autopsy specimens (27), indicating direct infection and replication in the kidney. These observations support that ACE2 is a functional receptor for SARS-CoV that can bind to the SARS-CoV S protein and undergo membrane fusion.

SARS-CoV-2 and SARS-CoV exhibited high homology (up to $79 \%$ ) on bioinformatics analysis (50). The affinity 

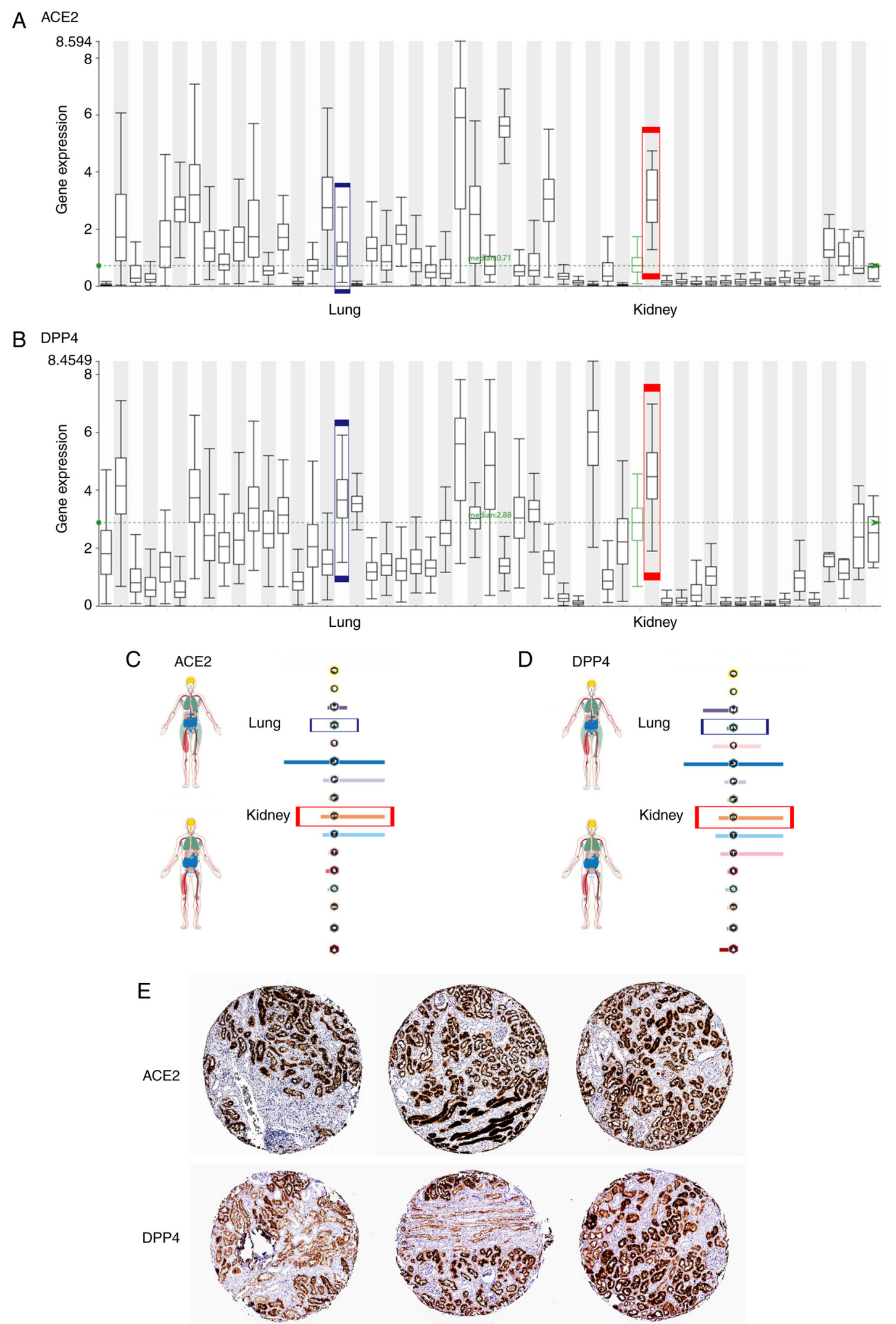

Figure 1. Analysis of ACE2 and DPP4 expression in different normal tissues using two databases. (A) ACE2 and (B) DPP4 expression data from A Database of Hepatocellular Carcinoma Expression Atlas. (C-D) ACE2 and DPP4 expression data from the Human Protein Atlas. (E) The ACE2 and DPP4 expression in kidney derived from the Human Protein Atlas (data was from antibody-based protein profiling using immunohistochemistry). Red box, kidney tissue; blue box, lung tissue. ACE2, angiotensin-converting enzyme 2; DPP4, dipeptidyl peptidase 4.

of SARS-CoV-2 was markedly higher compared with that of SARS-CoV when the S protein bound to the human
ACE2 (85). SARS-CoV-2 can use ACE2 to enter the recipient cells and activate the $\mathrm{S}$ protein by the serine protease 
TMPRSS2 on the host cell surface (76). Two studies that recently published online investigated the mechanism of how SARS-CoV-2 identifies and binds to human ACE2 and the composite crystal structure, which enhanced our understanding of the ACE2-mediated SARS-CoV-2 recognition and cell infection processes $(86,87)$. Pan et al $(88)$ concluded that the cytopathic effects of SARS-CoV-2 on podocytes and proximal straight tubule cells may cause AKI in patients with COVID-19, particularly those with evidence of SARS-CoV-2 infection in blood samples. Electron microscopic examination revealed that coronavirus particles were present in podocytes and renal tubular epithelial cells. In addition, immunostaining with SARS-CoV nucleoprotein antibody was positive in the tubules (58). SARS-CoV-2 nucleocapsid protein was detected in the renal tubular structure, and nucleocapsid protein-positive inclusion bodies were also observed in the renal cell cytoplasm (58). Researchers reported the presence of particles on the renal tubular epithelium, which were morphologically identical to SARS-CoV-2, and with viral arrays and other features of virus assembly, which constituted evidence of direct infection of the kidney by SARS-CoV-2 . This finding confirmed that direct renal infection occurs in the setting of AKI in COVID-19 (89). Patients infected with SARS-CoV and SARS-CoV-2 developed kidney injury that may be caused by a direct attack on kidney cells through ACE2. It remains unclear how the virus causes AKI after infecting the kidney cells.

DPP4 is considered to be a functional receptor for MERS-CoV (68-70). MERS-CoV causes renal dysfunction by infecting epithelial cells (90). Raj et al (68) found that DPP4 specifically copurified with the receptor-binding S1 domain of the MERS-CoV spike protein from lysates of susceptible Huh-7 cells. Antibodies directed against DPP4 can inhibit MERS-CoV infection of primary human bronchial epithelial cells and Huh-7 cells (68). Expression of human and bat DPP4 in non-susceptible COS-7 cells enabled infection by MERS-CoV (68). These works identified DPP4 as a functional receptor for MERS-CoV. Chinese researchers demonstrated that the MERS-CoV receptor-binding domain was composed of a core subregion and an external receptor-binding subregion. The core subdomain is highly homologous to the SARS-CoV spike molecule, but the external subdomain is highly variable (91). It is conceivable that DPP4 may be the receptor through which MERS-CoV infects renal cells and causes kidney injury.

In addition, immune activation caused by viral infection may release a large amount of inflammatory mediators (such as IL-1, IL-6 and TNF), resulting in kidney injury $(92,93)$. During the SARS outbreak, some critically ill patients experienced an inflammatory storm characterized by elevated IL-1 $\beta$, IL-6, IL-12, IFN- $\gamma$, IP10 and MCP-1 levels (94). The 'cytokine storm' caused by MERS coronavirus is primarily associated with IFN- $\gamma$, TNF- $\alpha$, IL-15 and IL-17 (95). SARS and MERS both induce a 'cytokine storm' in critically ill patients (96-98). COVID-19 patients may be affected by both the cytopathic effects directly induced by the virus as well as the systemic inflammatory responses caused by the cytokine storm, which may result in pathological changes in renal podocytes and proximal tubular cells and lead to AKI (88). Researchers analyzed the clinical characteristics of COVID-19 patients and found that, in patients with pneumonia, particularly in severe cases, there was a significant decrease in the lymphocyte count, and that a number of inflammatory factors (such as IL-6 and TNF) were increased significantly and that these may have caused kidney and other organ failure $(51,54,99)$. Researchers also indicated that the virus may enter the blood circulation after lung infection, accumulate in the kidneys and cause kidney damage (100). Patients with viral infections suffered from anorexia, diarrhea and excessive perspiration, which may lead to hypovolemia and renal hypoperfusion, eventually causing kidney injury (101). Notably, certain antibiotics and antiviral drugs are also likely to cause drug-related kidney injury $(102,103)$.

\section{Coronavirus and blood purification}

In addition to antiviral therapy and respiratory support, blood purification is also an important modality for treating coronavirus infections. According to the Kidney Diseases Improving Global Outcomes AKI guidelines, when continuous renal replacement therapy (CRRT) is used to treat COVID-19 patients, the therapeutic dose is $20-25 \mathrm{ml} / \mathrm{kg} / \mathrm{h}$ post-dilution and $25-30 \mathrm{ml} / \mathrm{kg} / \mathrm{h}$ predilution (104). Clinical studies demonstrated that the AKI incidence in COVID-19 patients was $3-7 \%$, and the proportion of patients on CRRT was $1.5-9.0 \%$; the AKI incidence in severe and critically ill patients admitted to the ICU was significantly increased, ranging from 8.3 to $23.0 \%$, and CRRT was required for 5.6-23.0\% of the patients, whereas CRRT was required for $66.7-100 \%$ of patients with AKI $(13,51,54)$. It was previously demonstrated that $6.7-11.1 \%$ of patients with SARS developed AKI and 1.8\% received CRRT (21). The incidence of AKI in MERS was 26.7 and 13.5-20\% patients with AKI received CRRT $(41,96)$. Up to $50 \%$ of MERS patients received CRRT (105). In addition, extracorporeal membrane oxygenation combined with CRRT was reported to effectively improve the patient's volume load and prognosis $(106,107)$. However, it is worth noting that patients receiving maintenance hemodialysis are susceptible to COVID-19 and that hemodialysis centers are high-risk settings for COVID-19 (108).

CRRT eliminates the overexpressed inflammatory factors and anti-inflammatory transmitters in the blood circulation non-selectively, reducing the peak concentrations of these factors and downregulating the body's inflammatory responses (109). Plasma replacement, adsorption, perfusion and other special blood purification treatment technologies are mainly used in the early and middle stages of cytokine storms in severe and critically ill patients with COVID-19, mainly to block disease progression by reducing IL-6 levels $(110,111)$. In addition to using antibodies against inflammatory factors, such as tocilizumab, to combat the cytokine storm $(112,113)$, blood purification treatment may also effectively suppress the cytokine storm and reduce the mortality rate of patients with severe COVID-19 $(110,114,115)$. However, according to a recent research, tocilizumab was not effective in preventing intubation or death in moderately ill hospitalized patients with COVID-19 (116). A benefit of dexamethasone was demonstrated in hospitalized patients with COVID-19 who were 
treated with either invasive mechanical ventilation or oxygen alone (117).

In summary, blood purification is a key therapeutic strategy against COVID-19, particularly in critically ill patients with or without renal failure, and it may improve the prognosis and outcome of these patients.

\section{Conclusion}

Kidney injury is an important clinical issue in coronavirus infection. The two currently identified receptors for coronavirus infection, ACE2 and DPP4, may be the key mediators triggering direct kidney injury by the coronavirus, while it remains unclear how the coronavirus causes kidney injury after entering renal cells. ACE2 and DPP4 are potential therapeutic targets, and target drugs are developed based on their structure to block virus invasion before injury occurs. Therefore, it is necessary to carry out further basic and clinical research to guide clinical practice. Blood purification is an important treatment measure in coronavirus infection with or without kidney injury. Early and timely blood purification therapy may reduce or prevent disease progression in patients with coronavirus infection.

The current COVID-19 epidemic is still not under control globally. Although the vaccine is currently used on patients, it is still necessary to focus on infection prevention in patients with kidney disease, study the pathogenic mechanism of COVID-19 in depth, and optimize the treatment strategies for severely ill patients with AKI in order to improve their prognosis.

\section{Acknowledgements}

Not applicable.

\section{Funding}

The present study was supported by the National Natural Sciences Foundation of China (grant nos. 81870498 and 81900633) and the National Natural Sciences Foundation of Hunan Province (grant no. 2017JJ2342).

\section{Availability of data and materials}

Not applicable.

\section{Authors' contributions}

ZF, HZ and WZ conceived and designed the study. YC, YW and JW contributed to drafted the manuscript and revised it critically for important intellectual content. ZF prepared the manuscript. All authors read and approved the final manuscript.

\section{Ethics approval and consent to participate}

Not applicable.

\section{Patient consent for publication}

Not applicable.

\section{Competing interests}

The authors declare that they have no competing interests.

\section{References}

1. Kapoor M, Pringle K, Kumar A, Dearth S, Liu L, Lovchik J, Perez O, Pontones P, Richards S, Yeadon-Fagbohun J, et al: Clinical and laboratory findings of the first imported case of Middle East respiratory syndrome coronavirus to the United States. Clin Infect Dis 59: 1511-1518, 2014.

2. Zhong NS, Zheng BJ, Li YM, Poon, Xie ZH, Chan KH, Li PH, Tan SY, Chang Q, Xie JP, et al: Epidemiology and cause of severe acute respiratory syndrome (SARS) in Guangdong, People's Republic of China, in February, 2003. Lancet 362: 1353-1358, 2003.

3. Plipat T, Buathong R, Wacharapluesadee S, Siriarayapon P, Pittayawonganon C, Sangsajja C, Kaewpom T, Petcharat S, Ponpinit T, Jumpasri J, et al: Imported case of Middle East respiratory syndrome coronavirus (MERS-CoV) infection from Oman to Thailand, June 2015. Euro Surveill 22: 30598, 2017.

4. Vijayanand P, Wilkins E and Woodhead M: Severe acute respiratory syndrome (SARS): A review. Clin Med 4: 152-160, 2004.

5. Muthumani K, Falzarano D, Reuschel EL, Tingey C, Flingai S, Villarreal DO, Wise M, Patel A, Izmirly A, Aljuaid A, et al: A synthetic consensus anti-spike protein DNA vaccine induces protective immunity against Middle East respiratory syndrome coronavirus in nonhuman primates. Sci Transl Med 7: 301ra132, 2015.

6. Paules CI, Marston HD and Fauci AS: Coronavirus infections-More Than Just the common cold. JAMA 323: 707-708, 2020.

7. Fehr AR and Perlman S: Coronaviruses: An overview of their replication and pathogenesis. Methods Mol Biol 1282: 1-23, 2015.

8. Zhang SF, Tuo JL, Huang XB, Zhu X, Zhang DM, Zhou K, Yuan L, Luo HJ, Zheng BJ, Yuen KY, et al: Epidemiology characteristics of human coronaviruses in patients with respiratory infection symptoms and phylogenetic analysis of $\mathrm{HCoV}-\mathrm{OC} 43$ during 2010-2015 in Guangzhou. PLoS One 13: e0191789, 2018.

9. Berry M, Gamieldien $J$ and Fielding BC: Identification of new respiratory viruses in the new millennium. Viruses 7: 996-1019, 2015.

10. Chan PK and Chan MC: Tracing the SARS-coronavirus. J Thorac Dis 5 (Suppl 2): S118-S121, 2013.

11. Zumla A, Hui DS and Perlman S: Middle East respiratory syndrome. Lancet 386: 995-1007, 2015.

12. Skariyachan S, Challapilli SB, Packirisamy S, Kumargowda ST and Sridhar VS: Recent aspects on the pathogenesis mechanism, animal models and novel therapeutic interventions for middle east respiratory syndrome coronavirus infections. Front Microbiol 10: 569, 2019

13. Chen N, Zhou M, Dong X, Qu J, Gong F, Han Y, Qiu Y, Wang J, Liu Y, Wei Y, et al: Epidemiological and clinical characteristics of 99 cases of 2019 novel coronavirus pneumonia in Wuhan, China: A descriptive study. Lancet 395: 507-513, 2020.

14. Heymann DL, Mackenzie JS and Peiris M: SARS legacy: Outbreak reporting is expected and respected. Lancet 381 : 779-781, 2013.

15. Anderson LJ and Tong S: Update on SARS research and other possibly zoonotic coronaviruses. Int J Antimicrob Agents 36 (Suppl 1): S21-S25, 2010.

16. Meo SA, Alhowikan AM, Al-Khlaiwi T, Meo IM, Halepoto DM, Iqbal M, Usmani AM, Hajjar W and Ahmed N: Novel coronavirus 2019-nCoV: Prevalence, biological and clinical characteristics comparison with SARS-CoV and MERS-CoV. Eur Rev Med Pharmacol Sci 24: 2012-2019, 2020.

17. Kuiken T, Fouchier RA, Schutten M, Rimmelzwaan GF, van Amerongen G, van Riel D, Laman JD, de Jong $\mathrm{T}$, van Doornum G, Lim W, et al: Newly discovered coronavirus as the primary cause of severe acute respiratory syndrome. Lancet 362: 263-270, 2003.

18. Fouchier RA, Kuiken T, Schutten M, van Amerongen G, van Doornum GJ, van den Hoogen BG, Peiris M, Lim W, Stöhr K and Osterhaus AD: Aetiology: Koch's postulates fulfilled for SARS virus. Nature 423: 240, 2003.

19. Peiris JS, Yuen KY, Osterhaus AD and Stöhr K: The severe acute respiratory syndrome. N Engl J Med 349: 2431-2441, 2003. 
20. Woodhead M, Ewig S and Torres A: Severe acute respiratory syndrome (SARS). Eur Respir J 21: 739-740, 2003.

21. Chu KH, Tsang WK, Tang CS, Lam MF, Lai FM, To KF, Fung KS, Tang HL, Yan WW, Chan HW, et al: Acute renal impairment in coronavirus-associated severe acute respiratory syndrome. Kidney Int 67: 698-705, 2005.

22. Lu HY, Xu XY, Lei Y, Wu YF, Chen BW, Xiao F, Xie GQ and Han DM: Clinical features of probable severe acute respiratory syndrome in Beijing. World J Gastroenterol 11: 2971-2974, 2005.

23. Lee N, Hui D, Wu A, Chan P, Cameron P, Joynt GM, Ahuja A, Yung MY, Leung CB, To KF, et al: A major outbreak of severe acute respiratory syndrome in Hong Kong. N Engl J Med 348: 1986-1994, 2003.

24. Hsu LY, Lee CC, Green JA, Ang B, Paton NI, Lee L, Villacian JS Lim PL, Earnest A and Leo YS: Severe acute respiratory syndrome (SARS) in Singapore: Clinical features of index patient and initial contacts. Emerg Infect Dis 9: 713-717, 2003.

25. Jang TN, Yeh DY, Shen SH, Huang CH, Jiang JS and Kao SJ: Severe acute respiratory syndrome in Taiwan: Analysis of epidemiological characteristics in 29 cases. J Infect 48: 23-31, 2004.

26. Cheng VC, Hung IF, Tang BS, Chu CM, Wong MM, Chan KH, Wu AK, Tse DM, Chan KS, Zheng BJ, et al: Viral replication in the nasopharynx is associated with diarrhea in patients with severe acute respiratory syndrome. Clin Infect Dis 38: 467-475, 2004.

27. Gu J, Gong E, Zhang B, Zheng J, Gao Z, Zhong Y, Zou W, Zhan J, Wang S, Xie Z, et al: Multiple organ infection and the pathogenesis of SARS. J Exp Med 202: 415-424, 2005.

28. Lang ZW, Zhang LJ, Zhang SJ, Meng X, Li JQ, Song CZ, Sun L, Zhou YS and Dwyer DE: A clinicopathological study of three cases of severe acute respiratory syndrome (SARS). Pathology 35: 526-531, 2003.

29. Ding Y, He L, Zhang Q, Huang Z, Che X, Hou J, Wang H, Shen H, Qiu L, Li Z, et al: Organ distribution of severe acute respiratory syndrome (SARS) associated coronavirus (SARS-CoV) in SARS patients: Implications for pathogenesis and virus transmission pathways. J Pathol 203: 622-630, 2004.

30. Peiris JS, Chu CM, Cheng VC, Chan KS, Hung IF, Poon LL, Law KI, Tang BS, Hon TY, Chan CS, et al: Clinical progression and viral load in a community outbreak of coronavirus-associated SARS pneumonia: A prospective study. Lancet 361: 1767-1772, 2003

31. Chan KH, Poon LL, Cheng VC, Guan Y, Hung IF, Kong J, Yam LY, Seto WH, Yuen KY and Peiris JS: Detection of SARS coronavirus in patients with suspected SARS. Emerg Infect Dis 10: 294-299, 2004.

32. Cheng PK, Wong DA, Tong LK, Ip SM, Lo AC, Lau CS, Yeung EY and Lim WW: Viral shedding patterns of coronavirus in patients with probable severe acute respiratory syndrome. Lancet 363: 1699-1700, 2004.

33. Zaki AM, van Boheemen S, Bestebroer TM, Osterhaus AD and Fouchier RA: Isolation of a novel coronavirus from a man with pneumonia in Saudi Arabia. N Engl J Med 367: 1814-1820, 2012.

34. Cho H, Excler JL, Kim JH and Yoon IK: Development of Middle East respiratory syndrome coronavirus vaccines-advances and challenges. Hum Vaccin Immunother 14: 304-313, 2018

35. Sun B, He H, Wang Z, Qu J, Li X, Ban C, Wan J, Cao B, Tong Z and Wang C: Emergent severe acute respiratory distress syndrome caused by adenovirus type 55 in immunocompetent adults in 2013: A prospective observational study. Crit Care 18: 456, 2014.

36. Al Ghamdi M, Alghamdi KM, Ghandoora Y, Alzahrani A, Salah F, Alsulami A, Bawayan MF, Vaidya D, Perl TM and Sood G: Treatment outcomes for patients with Middle Eastern respiratory syndrome coronavirus (MERS $\mathrm{CoV}$ ) infection at a coronavirus referral center in the Kingdom of Saudi Arabia. BMC Infect Dis 16: 174, 2016.

37. Sherbini N, Iskandrani A, Kharaba A, Khalid G, Abduljawad M and Al-Jahdali $\mathrm{H}$ : Middle East respiratory syndrome coronavirus in Al-Madinah City, Saudi Arabia: Demographic, clinical and survival data. J Epidemiol Glob Health 7: 29-36, 2017.

38. Eckerle I, Muller MA, Kallies S, Gotthardt DN and Drosten C: In-vitro renal epithelial cell infection reveals a viral kidney tropism as a potential mechanism for acute renal failure during Middle East Respiratory Syndrome (MERS) Coronavirus infection. Virol J 10: 359, 2013.

39. Poissy J, Goffard A, Parmentier-Decrucq E, Favory R, Kauv M, Kipnis E, Mathieu D, van der Werf S and Guery B; MERS-CoV Biology Group: Kinetics and pattern of viral excretion in biological specimens of two MERS-CoV cases. J Clin Virol 61: 275-278, 2014
40. Nassar MS, Bakhrebah MA, Meo SA, Alsuabeyl MS and Zaher WA: Middle East respiratory syndrome coronavirus (MERS-CoV) infection: Epidemiology, pathogenesis and clinical characteristics. Eur Rev Med Pharmacol Sci 22: 4956-4961, 2018

41. Cha RH, Joh JS, Jeong I, Lee JY, Shin HS, Kim G and Kim Y; Critical Care Team of National Medical Center: Renal Complications and their prognosis in Korean patients with Middle East respiratory syndrome-coronavirus from the central MERS-CoV designated hospital. J Korean Med Sci 30 $1807-1814,2015$

42. Alsaad KO, Hajeer AH, Al Balwi M, Al Moaiqel M, Al Oudah N, Al Ajlan A, AlJohani S, Alsolamy S, Gmati GE, Balkhy H, et al: 2. Histopathology 72: 516-524, 2018.

43. Ng DL, Al Hosani F, Keating MK, Gerber SI, Jones TL, Metcalfe MG, Tong S, Tao Y, Alami NN, Haynes LM, et al: Clinicopathologic, immunohistochemical, and Ultrastructural findings of a fatal case of Middle East respiratory syndrome coronavirus infection in the United Arab Emirates, April 2014 Am J Pathol 186: 652-658, 2016

44. Munster VJ, Koopmans M, van Doremalen N, van Riel D and de Wit E: A novel coronavirus emerging in china-key questions for impact assessment. N Engl J Med 382: 692-694, 2020

45. Zhu N, Zhang D, Wang W, Li X, Yang B, Song J, Zhao X, Huang B, Shi W, Lu R, et al: A Novel coronavirus from patients with pneumonia in China, 2019. N Engl J Med 382: 727-733, 2020.

46. Perlman S: Another decade, another coronavirus. N Engl J Med 382: 760-762, 2020.

47. Hui DS, I Azhar E, Madani TA, Ntoumi F, Kock R, Dar O, Ippolito G, Mchugh TD, Memish ZA, Drosten C, et al: The continuing 2019-nCoV epidemic threat of novel coronaviruses to global health-The latest 2019 novel coronavirus outbreak in Wuhan, China. Int J Infect Dis 91: 264-266, 2020.

48. Lu R, Zhao X, Li J, Niu P, Yang B, Wu H, Wang W, Song H, Huang B, Zhu N, et al: Genomic characterisation and epidemiology of 2019 novel coronavirus: Implications for virus origins and receptor binding. Lancet 395: 565-574, 2020.

49. Chan JF, Kok KH, Zhu Z, Chu H, To KK, Yuan S and Yuen KY: Genomic characterization of the 2019 novel human-pathogenic coronavirus isolated from a patient with atypical pneumonia after visiting Wuhan. Emerg Microbes Infect 9: 221-236, 2020.

50. Zhou P, Yang XL, Wang XG, Hu B, Zhang L, Zhang W, Si HR, Zhu Y, Li B, Huang CL, et al: A pneumonia outbreak associated with a new coronavirus of probable bat origin. Nature 579: 270-273, 2020

51. Wang D, Hu B, Hu C, Zhu F, Liu X, Zhang J, Wang B, Xiang H, Cheng Z, Xiong Y, et al: Clinical characteristics of 138 hospitalized patients with 2019 novel coronavirus-infected pneumonia in Wuhan, China. JAMA 323: 1061-1069, 2020.

52. Guan WJ, Ni ZY, Hu Y, Liang WH, Ou CQ, He JX, Liu L, Shan H, Lei CL, Hui DSC, et al: Clinical characteristics of coronavirus disease 2019 in China. N Engl J Med 382: 1708-1720, 2020

53. Yang X, Yu Y, Xu J, Shu H, Xia J, Liu H, Wu Y, Zhang L, Yu Z, Fang M, et al: Clinical course and outcomes of critically ill patients with SARS-CoV-2 pneumonia in Wuhan, China: A single-centered, retrospective, observational study. Lancet Respir Med 8: 475-481, 2020

54. Huang C, Wang Y, Li X, Ren L, Zhao J, Hu Y, Zhang L, Fan G, $\mathrm{Xu} \mathrm{J}, \mathrm{Gu}$ X, et al: Clinical features of patients infected with 2019 novel coronavirus in Wuhan, China. Lancet 395: 497-506, 2020.

55. Xu XW, Wu XX, Jiang XG, Xu KJ, Ying LJ, Ma CL, Li SB, Wang HY, Zhang S, Gao HN, et al: Clinical findings in a group of patients infected with the 2019 novel coronavirus (SARS-Cov-2) outside of Wuhan, China: Retrospective case series. BMJ 368 m606, 2020.

56. Cai Q, Huang D, Ou P, Yu H, Zhu Z, Xia Z, Su Y, Ma Z, Zhang Y, Li Z, et al: COVID-19 in a designated infectious diseases hospital outside Hubei Province, China. Allergy 75: 1742-1752, 2020.

57. Cheng Y, Luo R, Wang K, Zhang M, Wang Z, Dong L, Li J, Yao Y, Ge S and Xu G: Kidney disease is associated with in-hospital death of patients with COVID-19. Kidney Int 97: 829-838, 2020.

58. Su H, Yang M, Wan C, Yi LX, Tang F, Zhu HY, Yi F, Yang HC, Fogo $\mathrm{AB}$, Nie $\mathrm{X}$ and Zhang $\mathrm{C}$ : Renal histopathological analysis of 26 postmortem findings of patients with COVID-19 in China. Kidney Int 98: 219-227, 2020

59. Pei G, Zhang Z, Peng J, Liu L, Zhang C, Yu C, Ma Z, Huang Y, Liu W, Yao Y, et al: Renal involvement and Early prognosis in patients with COVID-19 pneumonia. J Am Soc Nephrol 31: $1157-1165,2020$ 
60. Chen YT, Shao SC, Lai EC, Hung MJ and Chen YC: Mortality rate of acute kidney injury in SARS, MERS, and COVID-19 infection: A systematic review and meta-analysis. Crit Care 24: 439, 2020.

61. Guery B, Poissy J, el Mansouf L, Séjourné C, Ettahar N, Lemaire X, Vuotto F, Goffard A, Behillil S, Enouf V, et al: Clinical features and viral diagnosis of two cases of infection with Middle East Respiratory Syndrome coronavirus: A report of nosocomial transmission. Lancet 381: 2265-2272, 2013.

62. Chan VW, Chiu PK, Yee CH, Yuan Y, Ng CF and Teoh JY: A systematic review on COVID-19: Urological manifestations, viral RNA detection and special considerations in urological conditions. World J Urol: May 27, 2020 (Epub ahead of print). doi: 10.1007/s00345-020-03246-4.

63. Müller MA, Raj VS, Muth D, Meyer B, Kallies S, Smits SL, Wollny R, Bestebroer TM, Specht S, Suliman T, et al: Human coronavirus EMC does not require the SARS-coronavirus receptor and maintains broad replicative capability in mammalian cell lines. mBio 3: e00515-12, 2012.

64. Monteil V, Kwon H, Prado P, Hagelkrüys A, Wimmer RA, Stahl M, Leopoldi A, Garreta E, Hurtado Del Pozo C, Prosper F, et al: Inhibition of SARS-CoV-2 infections in engineered human tissues using clinical-grade soluble human ACE2. Cell 181: 905-913.e7, 2020.

65. Hamming I, Timens W, Bulthuis ML, Lely AT, Navis G and van Goor H: Tissue distribution of ACE2 protein, the functional receptor for SARS coronavirus. A first step in understanding SARS pathogenesis. J Pathol 203: 631-637, 2004.

66. Rakušan D, Bürgelová M, Vaněčková I, Vaňourková Z, Husková Z, Skaroupková P, Mrázová I, Opočenský M, Kramer HJ, Netuka I, et al: Knockout of angiotensin 1-7 receptor Mas worsens the course of two-kidney, one-clip Goldblatt hypertension: Roles of nitric oxide deficiency and enhanced vascular responsiveness to angiotensin II. Kidney Blood Press Res 33: 476-488, 2010.

67. Li W, Moore MJ, Vasilieva N, Sui J, Wong SK, Berne MA, Somasundaran M, Sullivan JL, Luzuriaga K, Greenough TC, et al: Angiotensin-converting enzyme 2 is a functional receptor for the SARS coronavirus. Nature 426: 450-454, 2003.

68. Raj VS, Mou H, Smits SL, Dekkers DH, Müller MA, Dijkman R Muth D, Demmers JA, Zaki A, Fouchier RA, et al: Dipeptidyl peptidase 4 is a functional receptor for the emerging human coronavirus-EMC. Nature 495: 251-254, 2013.

69. Li F and Du L: MERS coronavirus: An emerging zoonotic virus. Viruses 11: 663, 2019.

70. Abdel-Moneim AS: Middle East respiratory syndrome coronavirus (MERS-CoV): Evidence and speculations. Arch Virol 159: 1575-1584, 2014.

71. Kenny AJ, Booth AG, George SG, Ingram J, Kershaw D, Wood EJ and Young AR: Dipeptidyl peptidase IV, a kidney brush-border serine peptidase. Biochem J 157: 169-182, 1976.

72. Lian Q, Wang S, Zhang G, Wang D, Luo G, Tang J, Chen L and Gu J: HCCDB: A database of hepatocellular carcinoma expression atlas. Genomics Proteomics Bioinformatics 16: 269-275, 2018.

73. Ponten F, Jirstrom $\mathrm{K}$ and Uhlen M: The human protein atlas-a tool for pathology. J Pathol 216: 387-393, 2008.

74. Uhlen M, Fagerberg L, Hallstrom BM, Lindskog C, Oksvold P, Mardinoglu A, Sivertsson Å, Kampf C, Sjöstedt E, Asplund A, et al: Proteomics. Tissue-based map of the human proteome. Science 347: 1260419, 2015.

75. Xu H, Zhong L, Deng J, Peng J, Dan H, Zeng X, Li T and Chen Q: High expression of ACE2 receptor of 2019-nCoV on the epithelial cells of oral mucosa. Int J Oral Sci 12: 8, 2020

76. Hoffmann M, Kleine-Weber H, Schroeder S, Krüger N, HerrlerT, Erichsen S, Schiergens TS, Herrler G, Wu NH, Nitsche A, et al: SARS-CoV-2 cell entry depends on ACE2 and TMPRSS2 and is blocked by a clinically proven protease inhibitor. Cell 181: 271-280.e8, 2020

77. Harmer D, Gilbert M, Borman R and Clark KL: Quantitative mRNA expression profiling of ACE 2, a novel homologue of angiotensin converting enzyme. FEBS Lett 532: 107-110, 2002.

78. Lely AT, Hamming I, van Goor H and Navis GJ: Renal ACE2 expression in human kidney disease. J Pathol 204: 587-593, 2004.

79. Pala L, Mannucci E, Pezzatini A, Ciani S, Sardi J, Raimondi L, Ognibene A, Cappadona A, Vannelli BG and Rotella CM: Dipeptidyl peptidase-IV expression and activity in human glomerular endothelial cells. Biochem Biophys Res Commun 310: 28-31, 2003.
80. Kuba K, Imai Y, Rao S, Gao H, Guo F, Guan B, Huan Y, Yang P, Zhang Y, Deng W, et al: A crucial role of angiotensin converting enzyme 2 (ACE2) in SARS coronavirus-induced lung injury. Nat Med 11: 875-879, 2005.

81. Ge XY, Li JL, Yang XL, Chmura AA, Zhu G, Epstein JH, Mazet JK, Hu B, Zhang W, Peng C, et al: Isolation and characterization of a bat SARS-like coronavirus that uses the ACE2 receptor. Nature 503: 535-538, 2013.

82. Strawn WB, Richmond RS, Ann Tallant E, Gallagher PE and Ferrario CM: Renin-angiotensin system expression in rat bone marrow haematopoietic and stromal cells. Br J Haematol 126: 120-126, 2004.

83. BatlleD, WysockiJ and SatchellK: Soluble angiotensin-converting enzyme 2: A potential approach for coronavirus infection therapy? Clin Sci 134: 543-545, 2020.

84. Yang XH, Deng W, Tong Z, Liu YX, Zhang LF, Zhu H, Gao H, Huang L, Liu YL, Ma CM, et al: Mice transgenic for human angiotensin-converting enzyme 2 provide a model for SARS coronavirus infection. Comp Med 57: 450-459, 2007.

85. Wrapp D, Wang N, Corbett KS, Goldsmith JA, Hsieh CL, Abiona O, Graham BS and McLellan JS: Cryo-EM structure of the 2019-nCoV spike in the prefusion conformation. Science 367: 1260-1263, 2020.

86. Shang J, Ye G, Shi K, Wan Y, Luo C, Aihara H, Geng Q, Auerbach A and Li F: Structural basis of receptor recognition by SARS-CoV-2. Nature 581: 221-224, 2020

87. Lan J, Ge J, Yu J, Shan S, Zhou H, Fan S, Zhang Q, Shi X, Wang Q, Zhang L and Wang X: Structure of the SARS-CoV-2 spike receptor-binding domain bound to the ACE2 receptor. Nature 581: 215-220, 2020

88.Pan XW, Xu D, Zhang H, Zhou W, Wang LH and Cui XG: Identification of a potential mechanism of acute kidney injury during the COVID-19 outbreak: A study based on single-cell transcriptome analysis. Intensive Care Med 46: 1114-1116, 2020.

89. Farkash EA, Wilson AM and Jentzen JM: Ultrastructural evidence for direct renal infection with SARS-CoV-2. J Am Soc Nephrol 31: 1683-1687, 2020.

90. Iwata-Yoshikawa N, Okamura T, Shimizu Y, Kotani O, Sato H, Sekimukai H, Fukushi S, Suzuki T, Sato Y, Takeda M, et al: Acute respiratory infection in human Dipeptidyl Peptidase 4-transgenic mice infected with Middle East respiratory syndrome coronavirus. J Virol 93: e01818-18, 2019.

91. Lu G, Hu Y, Wang Q, Qi J, Gao F, Li Y, Zhang Y, Zhang W, Yuan Y, Bao J, et al: Molecular basis of binding between novel human coronavirus MERS-CoV and its receptor CD26. Nature 500: 227-231, 2013

92. Deeks SG, Tracy R and Douek DC: Systemic effects of inflammation on health during chronic HIV infection. Immunity 39: 633-645, 2013

93. Wang W, Li G, De Wu, Luo Z, Pan P, Tian M, Wang Y, Xiao F, $\mathrm{Li} \mathrm{A}, \mathrm{Wu} \mathrm{K}$, et al: Zika virus infection induces host inflammatory responses by facilitating NLRP3 inflammasome assembly and interleukin-1 $\beta$ secretion. Nat Commun 9: 106, 2018.

94. Wong CK, Lam CW, Wu AK, Ip WK, Lee NL, Chan IH, Lit LC, Hui DS, Chan MH, Chung SS and Sung JJ: Plasma inflammatory cytokines and chemokines in severe acute respiratory syndrome. Clin Exp Immunol 136: 95-103, 2004.

95. Mahallawi WH, Khabour OF, Zhang Q, Makhdoum HM and Suliman BA: MERS-CoV infection in humans is associated with a pro-inflammatory Th1 and Th17 cytokine profile. Cytokine 104: 8-13, 2018.

96. Al-Jasser FS, Nouh RM and Youssef RM: Epidemiology and predictors of survival of MERS-CoV infections in Riyadh region, 2014-2015. J Infect Public Health 12: 171-177, 2019.

97. Reichsoellner M, Raggam RB, Wagner J, Krause R and Hoenigl M: Clinical evaluation of multiple inflammation biomarkers for diagnosis and prognosis for patients with systemic inflammatory response syndrome. J Clin Microbiol 52: 4063-4066, 2014

98. Hui DSC and Zumla A: Severe acute respiratory syndrome: Historical, epidemiologic, and clinical features. Infect Dis Clin North Am 33: 869-889, 2019.

99. Tisoncik JR, Korth MJ, Simmons CP, Farrar J, Martin TR and Katze MG: Into the eye of the cytokine storm. Microbiol Mol Biol Rev 76: 16-32, 2012.

100. Fani F, Regolisti G, Delsante M, Cantaluppi V, Castellano G, Gesualdo L, Villa G and Fiaccadori E: Recent advances in the pathogenetic mechanisms of sepsis-associated acute kidney injury. J Nephrol 31: 351-359, 2018. 
101. Martinez-Garcia JJ, Leon-Sicairos NM, Canizalez-Roman A and García-Arellano BA: Fluid balance and acute kidney injury in septic shock. Bol Med Hosp Infant Mex 74: 282-288, 2017 (In Spanish).

102. Jia X, Liu B, Bao L, Lv Q, Li F, Li H, An Y, Zhang X, Cao B and Wang C: Delayed oseltamivir plus sirolimus treatment attenuates H1N1 virus-induced severe lung injury correlated with repressed NLRP3 inflammasome activation and inflammatory cell infiltration. PLoS Pathog 14: e1007428, 2018.

103. Lorz C, Justo P, Sanz A, Subirá D, Egido J and Ortiz A: Paracetamol-induced renal tubular injury: A role for ER stress. J Am Soc Nephrol 15: 380-389, 2004.

104. Khwaja A: KDIGO clinical practice guidelines for acute kidney injury. Nephron. Clin Pract 120: c179-c184, 2012.

105. Al-Dorzi HM, Aldawood AS, Khan R, Baharoon S, Alchin JD, Matroud AA, Al Johany SM, Balkhy HH and Arabi YM: The critical care response to a hospital outbreak of Middle East respiratory syndrome coronavirus (MERS-CoV) infection: An observational study. Ann Intensive Care 6: 101, 2016.

106. Li Y, Cao C, Huang L, Xiong H, Mao H, Yin Q and Luo X: 'Awake' extracorporeal membrane oxygenation combined with continuous renal replacement therapy for the treatment of severe chemical gas inhalation lung injury. J Burn Care Res 41: 908-912, 2020.

107. Ostermann M, Connor M Jr and Kashani K: Continuous renal replacement therapy during extracorporeal membrane oxygenation: Why, when and how? Curr Opin Crit Care 24: 493-503, 2018

108. Xiong F, Tang H, Liu L, Tu C, Tian JB, Lei CT, Liu J, Dong JW, Chen WL, Wang XH, et al: Clinical characteristics of and medical interventions for COVID-19 in hemodialysis patients in Wuhan, China. J Am Soc Nephrol 31: 1387-1397, 2020.

109. Ronco C, Tetta C, Mariano F, Wratten ML, Bonello M, Bordoni V, Cardona X, Inguaggiato P, Pilotto L, d'Intini V and Bellomo R: Interpreting the mechanisms of continuous renal replacement therapy in sepsis: The peak concentration hypothesis. Artif Organs 27: 792-801, 2003
110. Ma J, Xia P, Zhou Y, Liu Z, Zhou X, Wang J, Li T, Yan X, Chen L, Zhang S, et al: Potential effect of blood purification therapy in reducing cytokine storm as a late complication of critically ill COVID-19. Clin Immunol 214: 108408, 2020.

111. Tang B, Li S, Xiong Y, Tian M, Yu J, Xu L, Zhang L, Li Z, Ma J, Wen F, et al: COVID-19 pneumonia in a hemodialysis patient. Kidney Med 2: 354-358, 2020.

112. Xu X, Han M, Li T, Sun W, Wang D, Fu B, Zhou Y, Zheng X, Yang Y, Li X, et al: Effective treatment of severe COVID-19 patients with tocilizumab. Proc Natl Acad Sci USA 117: 10970-10975, 2020.

113. Fu B, Xu X and Wei H: Why tocilizumab could be an effective treatment for severe COVID-19? J Transl Med 18: 164, 2020.

114. Yang XH, Sun RH, Zhao MY, Chen EZ, Liu J, Wang HL, Yang RL and Chen DC: Expert recommendations on blood purification treatment protocol for patients with severe COVID-19: Recommendation and consensus. Chronic Dis Transl Med 6: 106-114, 2020

115. Zhang Y, Yu L, Tang L, Zhu M, Jin Y, Wang Z and Li L: A promising anti-cytokine-storm targeted therapy for COVID-19: The artificial-liver blood-purification system. Engineering (Beijing): Mar 20, 2020 (Epub ahead of print). doi: 10.1016/j. eng.2020.03.006

116. Stone JH, Frigault MJ, Serling-Boyd NJ, Fernandes AD, Harvey L, Foulkes AS, Horick NK, Healy BC, Shah R, Bensaci AM, et al: Efficacy of tocilizumab in patients hospitalized with Covid-19. N Engl J Med 383: 2333-2344, 2020.

117. RECOVERY Collaborative Group; Horby P, Lim WS Emberson JR, Mafham M, Bell JL, Linsell L, Staplin N, Brightling C,Ustianowski A, et al: Dexamethasone in hospitalized patients with Covid-19-preliminary report. N Engl J Med: Jul 17, 2020 (Epub ahead of print). doi: 10.1056/NEJMoa2021436.

(i) (5) $\ominus$ This work is licensed under a Creative Commons Attribution-NonCommercial-NoDerivatives 4.0 International (CC BY-NC-ND 4.0) License. 